Vol. 8, No. 2, 2020, pp. 86-91

DOI: https://doi.org/10.29210/142900

Contents lists available at Jurnal IICET

Jurnal Konseling dan Pendidikan

ISSN: 2337-6740 (Print) ISSN: 2337-6880 (Electronic)

Journal homepage: http://jurnal.konselingindonesia.com

\title{
Peningkatan harga diri melalui layanan bimbingan dan konseling individu
}

\author{
Umar Latif $^{1}$, Zamratul Aini ${ }^{2}$ \\ ${ }^{12}$ Universitas Islam Negeri Ar-Raniry
}

\section{Article Info \\ Article history: \\ Received Apr 28th, 2020 \\ Revised Mei 30th, 2020 \\ Accepted Jun 22nd, 2020}

\section{Keyword:}

Islamic counseling

Self esteem

Fostered woman

Correctional institution

Sigli, pidie regency

Aceh

\begin{abstract}
Foster women are more prone to psychological problems than foster men. One psychological problem that is usually experienced by prisoners is low selfesteem. one solution to increase self-esteem can be done through individual counseling services. The purpose of this study is to determine the effectiveness of Islamic counseling in increasing the self-esteem of the target people. The method used in this study is qualitative with a Participatory action research approach. The sample in this study amounted to 3 people, using purposive sampling technique. Data were analyzed through scanning material in the field, general sense, and coding data. The results of the study found an increase in self-esteem in foster citizens marked by the emergence of 5 of 7 aspects based on realistic behavior checklist indicators, aware of strengths and weaknesses, aware of the position as God's creatures, assertive and independent.
\end{abstract}

\section{Corresponding Author:}

Umar Latif,

Universitas Islam Negeri Ar-Raniry

Email: umar.latif@ar-raniry.ac.id

\section{Pendahuluan}

Keberadaan lembaga permasyarakatan di Indonesia memegang peranan penting guna memberikan pembinaan kepada masyarakat yang melakukan tindakan kejahatan. Tindakan kejahatan dapat muncul sebagai akibat adanya perubahan zaman yang tidak dibarengi dengan kesejahteraan ekonomi dan sosial. Salah satu bukti dari permasalahan tersebut terlihat dari angka pengangguran yang meningkat sebesar 10\% dan angka kemiskinan sekitar 23\% pada tahun 2010 (Pujianto, 2010). Oleh karena itu, tingginya angka pengangguran dapat memicu berbagai masalah, salah satunya seperti kriminalitas.

Pelaku kriminalitas yang mendapatkan hukuman ditempatkan di berbagai lembaga permasyarakatan dan disebut sebagai warga binaan (Mujiran, 2006). Warga binaan yang menjalani hukuman dalam rentang waktu lama di Lembaga Permasyarakatan (Lapas) tentu akan mengalami permasalahan psikologis. Permasalahan tersebut antara lain kehilangan keluarga, kehilangan kontrol diri, kehilangan rasa percaya diri dan kurangnya dukungan (Koesno, 2007). Selain itu (Thirsia, 2011) mengatakan bahwa dampak psikologis lainnya yang dialami seperti merasakan tidak bermakna yang ditandai dengan perasaan hampa, bosan dan penuh keputusasaan serta tidak memiliki tujuan hidup. Berdasarkan itu, maka jika permasalahan psikologis ini tidak ditangani dengan tepat tentu akan menjadi sumber masalah yang baru.

Permasalahan psikologis yang dirasakan warga binaan dapat berbeda-beda antara satu orang dengan orang lainnya. Setiap beban psikologis yang dirasakan dipengaruhi oleh berbagai faktor, salah satunya adalah jenis kelamin. Menurut penelitian Gussak (2009), warga binaan perempuan cenderung lebih rentan terhadap permasalahan psikologis dibandingkan laki-laki. James dan Glaze (2006) menyampaikan bahwa warga binaan perempuan di AS mengalami masalah kesehatan jiwa lebih tinggi (75\%) dibandingkan warga binaan laki-laki (55\%) (James \& Glaze, 2006). Hal serupa juga ditemukan oleh Utami dan Pratiwi (2011) dalam penelitiannya bahwa warga binaan perempuan lebih rentan mengalami stress dibandingkan dengan 
warga binaan laki-laki (Utami \& Pratiwi, 2011). Menurut Fauziya dan Ike (2013) warga binaan perempuan lebih mudah mengalami permasalahan psikologis karena kesulitan beradaptasi dengan status baru yang disandang dan adanya ketakutan dengan stigma dari masyarakat (Fauziya \& Ike 2013). Beberapa literatur lainya mendukung bahwa meskipun baik laki-laki maupun perempuan mempunyai masalah psikologis yang serupa, namun perempuan lebih sulit menangani permasalahan psikologis yang dialami.

Diantara beberapa masalah psikologis yang sering dialami warga binaan adalah rendahnya harga diri. Hal ini didukung oleh penelitian yang dilakukan oleh I gusti Ngurah Juniartha (2012) di Denpasar menyebutkan sebanyak 56,2\% warga binaan memiliki tingkat harga diri yang rendah (Juniartha, 2012). Penelitian lain menemukan $80 \%$ warga binaan perempuan di Lapas Palembang mengalami depresi sedang dengan salah satu gejala adalah harga diri rendah (Inayatika, 2012). Selain itu hal serupa juga ditemukan pada warga binaan di Lapas kelas IIA Bogor dimana salah satu masalah yang banyak dikeluhkan oleh warga binaan perempuan adalah harga diri yang rendah (Hidayati, 2011). Warga binaan yang memiliki harga diri rendah cenderung merasa tidak berguna, putus asa (Nova, 2008), tidak berdaya dan tidak mempunyai motivasi untuk bekerja dan beraktivitas (Videbeck, 2008). Tidak berbeda jauh dengan tempat lainnya, rendahnya harga diri pada warga binaan juga ditemukan di Aceh, yaitu di Lapas Kelas III Perempuan Sigli. Berikut kutipan wawancara yang dilakukan.

Kehidupan saya sekarang tidak berguna lagi, saya tidak bisa melakukan hal yang bermanfaat lagi, karena saya merasa malu dan merasa diri sebagai penjahat atas perilaku yang saya lakukan selama ini. (hasil wawancara warga binaan S, asgustus 2019). Selama saya di lapas keluarga saya sudah tidak damai lagi, dimana suami saya sudah menikah lagi dengan perempuan yang baik dan lebih cantik dari saya, saya sekarang seperti sampah yang tidak ada gunanya lagi, padahal apa saya lakukan untuk membantu nafkah keluarga. (hasil wawancara warga binaan M, asgustus 2019).

Berdasarkan hasil wawancara di Lapas Kelas III Perempuan Sigli yang dilakukan pada tanggal 20 Agustus 2019, diketahui bahwa warga binaan mengalami tekanan psikologis yang disebabkan oleh beberapa hal, seperti masa tahanan yang cukup lama, tidak mampu menyesuaikan diri dalam menjalani kehidupan di lapas, dan adanya kekhawatiran ketika keluar dari lapas, masyarakat akan sulit menerima mereka kembali. Perilaku dan pemikiran yang negatif mencerminkan harga diri yang rendah (Sipayung, 2007). Lestari (2002) mengatakan bahwa individu yang memiliki harga diri yang rendah maka akan memberikan penghargaan yang buruk ke dirinya sendiri sehingga pada akhirnya kesulitan beradaptasi dengan lingkungan sosialnya (Lestari, 2002)

Beberapa solusi telah dilakukan untuk menangani permasalahan ini, seperti penelitian yang dilakukan oleh Maryatun (2014) yang menemukan bahwa logoterapi efektif meningkatkan harga diri narapidana perempuan yang menggunakan Narkotika (Maryatun, 2014). Selain itu Hidayati (2011) menemukan emotional freedom techniue efektif meningkatkan harga diri pada narapidana perempuan di Lapas Bogor. Selanjutnya penelitian yang dilakukan oleh Sacks (2008) menemukan bahwa konseling kelompok efektif membantu kecemasan warga binaan perempuan. penelitian yang dilakukan oleh Gordon (2007) yang menemukan bahwa konseling efektif dilakukan pada warga binaan yang akan bebas. Selain itu dari penelitiannya ditemukan bahwa para warga binaan yang mendapatkan konseling efektif mengurangi peluang mereka kembali lagi ke tahanan. Berdasarkan hal tersebut maka layanan konseling dengan berbagai pendekatan dapat menjadi solusi untuk permasalahan psikologis warga binaan seperti untuk meningkatkan harga diri warga binaan.

Salah satu pendekatan layanan konseling yang akan dilakukan oleh peneliti yaitu layanan konseling individu berbasis Islam. Tujuan layanan ini untuk mengembalikan kesadaran pada setiap individu berdasarkan eksistensinya sebagai makhluk Allah yang seharusnya hidup selaras dengan ketentuan dan petunjuk Allah. Sehingga dapat mencapai kebahagiaan hidup di dunia dan akhirat (Musnamar, 1992). Pemberian layanan konseling Islami ini dilakukan berdasarkan pertimbangan lokasi Daerah syariat Islam. Sebagai daerah syari'at Islam setiap permasalahan kehidupan dapat mudah diterima dengan pendekatan nilai-nilai Islami. Selain itu faktor lainnya adalah penelitian mengenai layanan konseling islami telah banyak dilakukan pada berbagai responden penelitian, seperti pada siswi SMP (Fuadillah, 2019), penyakit kronis (Hidayanti, 2012), muallaf (Sujarwo, 2017), penderita multiple sclerosis (Layla, 2019), dan lainnya. Namun diantara banyaknya penelitian yangg mengkaji layanan konseling Islam, belum ada penelitian yang mengkaji pembersian layanan konseling Islam pada warga binaan Lapas Kelas III Perempuan Sigli, Aceh. Fakta-fakta yang telah dipaparkan tersebut menjadi dasar peneliti untuk melakukan penelitian ini dengan tujuan untuk mengetahui efektifitas konseling islami (layanan konseling individu) dalam meningkatkan harga diri warga binaan di Lembaga Pemasyarakatan Perempuan Kelas III Sigli. 
Tujuan dari penelitian ini adalah untuk mengetahui efektivitas konseling islami (layanan konseling individu) dalam meningkatkan harga diri warga binaan di Lembaga Pemasyarakatan Perempuan Kelas III Sigli. Berdasarkan tujuan tersebut, maka manfaat secara teoritis yang diperoleh dari penelitian ini adalah dapat menambah konstruksi kajian secara ilmiah dalam konteks layanan konseling Islami terkait peningkatan harga diri bagi warga binaan di Lapas Kelas III perempuan Sigli, sedangkan secara praktis, penelitian ini diharapkan menjadi solusi terhadap permasalahan psikologis warga binaan perempuan di Lapas Kelas III Sigli. Selain itu, penelitian ini juga dapat menjadi salah satu upaya penerapan konseling Islami di lingkungan lapas di Aceh. Hasil penelitian ini nantinya dapat menjadi sarana informasi ekstra kepada masyarakat dan lingkungan sekitarnya secara umum mengenai permasalahan psikologis warga binaan perempuan.

\section{Metode}

Penelitian ini merupaan penelitian berbasis pengabdian masyarakat dengan tujuan untuk mengkaji secara komprehensif bimbingan dan konseling Islam dan implikasinya dalam peningkatan harga diri warga binaan di Lapas Kelas III Perempuan Sigli. Jenis pendekatan yang digunakan adalah pendekatan kualitatif. Penelitian berlokasi di Lapas Kelas III perempuan Sigli dan sampel yang diambil hanya 4 orang saja. Pemilihan sampel dilakukan berdasarkan kriteria yang telah ditetapkan peneliti yaitu warga binaan yang akan selesai masa hukumannya dan baru pertama kali mendapatkan hukuman penjara. Metode pengumpulan data dalam penelitian ini menggunakan 3 cara merujuk pada jenis penelitian ini, yaitu observasi, pemberian layanan konseling individu yang dilaksanakan pada tanggal 11 Juni - 11 Agustus 2019 di Lapas wanita kelas III Sigli dan dokumentasi. Analisis data dilaksanakan setelah pelaksanaan kegiatan melalui teknik pengumpulan data, penyajian data, mereduksi data, mengambil kesimpulan.

\section{Hasil dan Pembahasan}

Berdasarkan hasil wawancara di Lapas Kelas III Perempuan Sigli yang dilakukan pada tanggal 20 Agustus 2018, diketahui bahwa warga binaan mengalami tekanan psikologis yang disebabkan oleh beberapa hal, seperti masa tahanan yang cukup lama, tidak mampu menyesuaikan diri dalam menjalani kehidupan di lapas, dan adanya kekhawatiran ketika keluar dari lapas, masyarakat akan sulit menerima mereka kembali. Permasalahan ini menyebabkan warga binaan merasa tidak berharga, tidak memiliki masa depan dan tidak berarti di lingkungan masyarakat nantinya.

Permasalahan rendahnya harga diri yang dimiliki warga binaan tentunya dapat menjadi masalah baru ketika tidak diselesaikan dengan tepat. Salah satu cara yang dapat dilakukan adalah pemberian layanan konseling pada warga binaan yang akan berakhir masa tahanannya. Adapun layanan konseling yang diberikan kepada warga binaan di Lapas kelas III perempuan sigli yaitu konseling individu. Layanan konseling individu dapat diselenggarakan oleh seorang konselor terhadap seorang klien dalam rangka pengentasan masalah klien (Willis, 2004). Menurut Gibson, mitchell dan Basile dalam jurnal Nikmarjjal (2020), ada beberapa tujuan dari konseling individu, diantaranya: a), tujuan perekembangan yaitu klien yang dibantu dalam proses peretumbuhan dan perkembangannya serta mengantisipasi halhal yang akan terjadi, b). Tujuan pencegahan yaitu konselor yang membantu klien menghindari suatu hal atau hasil-hasil yang tidak diinginkan dan berdampak buruk. c) tujuan fisiologis, yaitu menghasilkan pemahaman dasar dan kebiasaan untuk hidup sehat, d) tujuan psikologis yaitu membantu mengembangkan keterampilan sosial yang baik, belajar mengontrol emosi, dan mengembangkan konsep diri positif dan sebagainya. Adapun faktor-faktor yang pendukung dalam pelakasnaan konseling, yaitu: struktur, inisiatif, seting fisik, kualitas klien, dan kualitas konselor. Glading (2012).

Pada penelitian ini, aspek harga diri yang digunakan berdasarkan teori Widarso Ahmad yang menyatakan ada delapan aspek harga diri yaitu menyadari bahwa semua orang adalah ciptaan tuhan, mandiri, menyadari dan memanfaatkan kelebihan, berpengetahuan luas, realistis, asertif dan mampu menggunakan bahasa verbal dan nonverbal. Namun, pada Penelitian ini peneliti mengambil 3 aspek self esteem ditinjau dari self esteem rendah, yaitu; tidak menyadari sebagai makhluk Tuhan, tidak percaya diri, dan tidak mandiri.

Tidak menyadari sebagai makhluk Tuhan

Hasil observasi harga diri warga binaan berada pada kategori rendah, dengan sikap, warga binaan tidak melaksanakan kewajiban-kewajiban ibadah selama berada di Lapas cenderung mereka beranggapan yang terjadi pada dirinya adalah siksa dari Allah, berprasangka buruk kepada Allah, dan bahkan warga binaan 
merasakan kasih sayang Allah sudah hilang dari kehidupannya, dan jarang melakukan aktivitas yang wajib apalgi yang sunnah. Berikut kutipan wawancara yang dilakukan.

Saya pernah menjadi alumni dari pesantren, saya paham bagaimana cara mengerjakan sholat dan bagaimana saya harus bertaubat, tetapi ketika saya hendak memulainya saya merasa tidak ada gunanya juga lagian saya sudah menjadi orang yang jahat dengan eksrpesi menangis, . (hasil wawancara warga binaan asgustus 2019).

\section{Tidak percaya diri}

Hasil observasi ditemukan harga diri warga binaan berada pada kategori rendah, dimana sikap warga binaan tidak percaya diri, merasa diri tidak bahagia, tidak yakin dengan takdir yang terjadi pada dirinya, menyalahkan Tuhan atas apa yang terjadi dalam kehidupannya, tidak mau memberikan informasi kepada rekan-rekannya meskipun paham terkait informasi tersebut, merasa terbebani dalam melakukan sesuatu dan ragu dalam mengambil keputusan terkait masa depannya. Hasil kutipan wawancara sebagai berikut:

Kehidupan dipenjara ini, merasa Allah itu tidak pernah sayang dengan saya, saya melakukan semuai ini untuk menafkahi keluarga saya, cobalah dibayangkan anak saya sekarang tinggal bersama orangtua saya yang kehidupan ekonominya sangat tidak memadai (hasil wawancara warga binaan asgustus 2019).

Saya selalu dipantau, seakan saya sendiri yang salah disini dari jauh pegawai sudah menyudutkan pandanganya kepada saya, kalau ada kesalahpahaman saya dengan teman yang lain selalu saya yang disalahkan (hasil wawancara warga binaan asgustus 2019).

\section{Tidak mandiri}

Hasil observasi dengan beberapa warga binaan, ditemukan harga diri berada pada kategori rendah salah satunya adalah ketidakmandirian warga binaan dalam melakukan dan menerapkan aturan-aturan yang ada dalam LAPAS. Dilihat dari sikap tidak mampu mengungkapkan perasaannya secara terus terang mengenai masalah yang dihadapi, warga binaan tidak mampu menyesuaikan diri dengan rekan-rekan yang ada dilapas, tidak mengikuti kegiatan-kegiatan dan program yang dilaksankan di Lapas, dan merasa tidak bebas dalam melakukan segala sesuatu sesuai dengan keinginannya.

Perasaan saya dan masalah yang saya hadapi terlalu berat dan saya merasa semuanya akan sia-sia jika saya menceritakan kepada teman yang ada dalam lapas ini, lagian statusnya sama-sama sebagai tahanan, lebih baik saya ambil diam dan tidak menceritakan masalah ini kepada orang lain (hasil wawancara warga binaan agustus 2019).

"Saya merasa terkukung hidup dilapas, saya tidak bebas mengeluarkan ide-ide saya karena biar bagaimana pun sattus saya tetap sebagai penjahat dan tahanan, dan saya merasa diri ini tidak berguna lagi" (hasil wawancara warga binaan Agustus 2019).

Hasil penelitian menunjukkan bahwa harga diri warga binaan berada kategori sedang. Setelah menerapkan konseling individu. Berdasarkan daftar cek perilaku terkait harga diri, dan pengabdian selema bulan Juni dan Agustus 20019. Konseling individu dilaksanakan untuk mengurangi ketidak mandirian, merasa tidak mempunyai kelebihan, dan pesimis dalam menjalani hidup. Hasil perubahan sikap yang terjadi sebagai berikut: Pemberian layanan konseling individu dimulai pada bulan Juli-Agustus 2019 Layanan konseling individu dilakukan 3 kali dalam seminggu selama sebulan. Layanan konseling individu diberikan pada 3 warga binaan yang dipilih oleh pegawai Lapas perempuan kelas III Sigli. Adapun hasil perubahan perilaku sebagai berikut: 1) Setelah sesi konseling individual, warga binaan sudah mampu mengatur dirinya sendiri dan mengarahkan hidupnya sendiri, sudah mandiri dalam penyelesaian masalah pribadi, dan warga binaan sudah mulai aktif membagi informasi kepada rekan sejawat; 2) Warga binaan sudah mulai menunjukkan sikap optimis, dalam menjalani hidup, tidak berputus asa dan selalu memperbaiki dirinya dengan melakukan hal-hal yang positif seperti ikut bergabung dengan rekan sejawat, melaksanakan kegiatan yang ada di LAPAS dengan baik (hasil observasi pegawai lapas September 2019); 3) Warga binaan Menyadari potensi-potensi yang dimiliki dan dikembangkan dengan berpartisipasi aktif dalam kegiatan; 4) Menyesuaikan diri dengan lingkungan Lapas dan bisa menerima kekurangan diri di lapas; 5) Memiliki kekuasaan diri dan menilai diri secara positif. 


\section{Kesimpulan}

Berdasarkan penelitian ini ditemukan beberapa indikator perilaku yang menandakan rendahnya harga diri, yaitu tidak merasa mempunyai kelebihan, tidak mandiri, tidak yakin dengan kemampuan diri, pesimis, tidak mempunyai pikiran yang realistis dan pasif. Setelah diberikan layanan konseling individu ada perubahan yang dialami oleh warga binaan seperti adanya sikap optimis, menerima kekurangan diri, menyadari potensi yang dimiliki dan aktif mengikuti kegiatan. Penelitian ini tentunya tidak lepas dari beberapa kendala yang terjadi di lapangan, seperti sesi konseling individu yang sesekali harus bergeser atau ditunda karena ada kunjungan keluarga atau karena warga binaan tidak ada minat konseling pada hari tersebut. Meskipun ada banyak penelitian serupa yang pernah dilakukan, namun penelitian ini berbeda dengan penelitian sebelumnya. Perbedaan tersebut ada pada lokasi, kriteria responden dan layanan konseling individu yang diberikan. Layanan konseling Islami dianggap tepat diberikan di Lapas Kelas III Perempuan, Sigli dikarenakan masyarakat lebih mudah menerima pendekatan agama dibandingkan pendekatan konvensional. Penelitian ini penting sekali dilakukan mengingat di Lapas tersebut tidak mempunyai layanan konseling individu yang memadai dan berkualitas. Sehingga hasil penelitian ini diharapkan menjadi masukan kepada pihak Lapas Wanita Kelas III Sigli agar meningkatkan kualitas dan kuantitas pelayanan konseling bagi warga binaan yang mengalami permasalahan psikologis. Untuk penelitian selanjutnya, peneliti menyarankan untuk mencoba layanan konseling individu pada permasalahan psikologis lainnya seperti kecemasan yang dirasakan ketika warga binaan selesai menjalani hukuman.

\section{Referensi}

Al-Qur'an dan Terjemahannya. (1998). Departemen Agama Republik Indonesia.

Fauziya A, \& Ike H. (2013). Penerimaan Diri pada Narapidana Wanita. Jurnal Psikologi Kepribadian dan Sosial, 02,01,

Fuadillah, M. Z. (2019). Konseling Islam Dengan Terapi Naratif Dalam Mengatasi Konsep Diri Negatif Seorang Siswi Smp Islam Tanwirul Afkar Sidoarjo. Tesis. Malang. Universitas Islam Negeri Sunan Ampel.

Gladding, T. Samuel. (2012). Konseling : profesi yang Menyeluruh. Indeks: Jakarta.

Gordon, M. S., T. W. Kinlock, et al. (2008).A randomized clinical trial of methadone maintenance for prisoners: Findings at 6 months post-release. Addiction. 103,(8), 1333-1342.

Gussak, D. (2009). The Effects of Art Theraphy on Male and Female Inmates : Advancing the Reserchbase. The Arts in Psychotheraphy.

Hidayati, N.O. dkk. (2011). Pengaruh Emotional Freedom Technique (EFT) Terhadap Peningkatan Harga Diri Narapidana Perempuan Di Lembaga Pemasyarakatan Kelas Iia Bogor.Journal Keperawatan UNPAD. 13,02,

Hidayanti, E. (2012). Konseling Islam Bagi Individu Berpenyakit Kronis Morbus Hansen. Konseling Religi. Jurnal Bimbingan Konseling Islam. 03,02.

Inayatika. (2011). Self efficacy pada narapidana dilapas kelas I Palembang. Tesis. Palembang: Program Studi Ilmu Keperawatan UNSRI, Palembang.

James, D.J., \& Glaze, L.E. (2006). Beraue ojustice statistic special report: Mentahealth problem of prison and jail inmates. Diperoleh dari: https://www.bjs.gov/contenpub/pdf/mhppji.pdf.

Juniartha, I. G. N.(2015). Hubungan Antara Harga Diri (Self-Esteem) Dengan Tingkat Stres Narapidana Wanita Di Lapas Klas Iia Denpasar. Commmunity of publishing in nursing. 03, 14

Koesno, A. (2007). Faktor-faktor kriminogenik perempuan melakukan kejahatan narkotika. Jurnal Yustika, $10(2), 153-170$.

Kholil,S. (2009). Bimbingan Konseling Dalam Perspektif Islam.Medan: Citapustaka Media Perintis.

Layla,, R. (2019). Konseling Islam Dengan Sholawat Thibbil Qulub Untuk Meningkatkan Spiritualitas Pada Penderita Multiple Sclerosis Di Desa Belahanrejo Kedamean Gresik. Tesis.

Lestari, R.. (2002). Pelatihan Berfikir Optimis untuk Meningkatkan Harga Diri Pelacur yang Tinggal di Panti dan Luar Panti Sosial. Indigenous, 6, 134-146.

Lubis, S.A.(2015). Konseling Islami dalam Komunitas Pesantren. Bandung: Cita Pustaka

Maryatun, 2014. Logoterapi Meningkatkan Harga Diri Narapidana Perempuan Pengguna Narkotika .Jurnal Keperawatan Indonesia, 17,02, 48-56

Mujiran, P. (2006). Kejahatan dan gangguan jiwa. Diperoleh dari http://groups.yahoo.com/.

Musnamar, T. (1992). Dasar-Dasar Konseptual Bimbingan Konseling Islam Yogyakarta: UII PRESS.

Nikmarijal, \& Saiful. (2020). "Meningkatkan self esteem melalui layanan konseling individual menggunakan pendekatan rational Emotif behaviour". Journal of counseling and Education.1 (1): 6-12 
Nova.S. (2008). Tingkat depresi pada narapidana wanita di lembaga pemasyarakatan IIA Palembang. Tesis. Palembang : Program Studi Ilmu Keperawatan UNSRI.

Prayitno. (2013), Panduan Kegiatan Pengawasan Bimbingan dan Konseling Di Sekolah, Jakarta: PT. Rineka Cipta Pujianto, R. (2010). Angka pengangguran. Diperoleh dari: http://www.MediaIndonesia.com.

Willis, Sofiyan S. (2004). Konseling Individu Teori dan Praktek. Bandung: Alfabeta

Sacks, J. Y., S. Sacks, et al. (2008). "Prison therapeutic community treatment for female offenders: Profiles and preliminary findings for mental health and other variables (crime, substance use and HIV risk)." Journal of Offender Rehabilitation 46(3-4): 233-261.

Sipayung, M. (2007). Pengaruh pelatihan asertivitas terhadap peningkatan harga diri. Jurnal Pendidikan Matematika dan Sains, 2, 33-37.

Sujarwo, T.S. (2017). Dampak Model Bimbingan Dan Konseling Islam Terhadap Perilaku Keagamaan Muallaf Di Pusat Rehabilitasi Aqidah. Jurnal Bimbingan Dan Konseling. 02, 01

Thirsia, S.G. (2011). Hubungan Harga Diri Dengan Makna Hidup Pada Narapidana. Diakses dari http://repository.usu.ac.id/handle/123456789/23405 pada tanggal 24 Juni 2020.

Utami R, R \& Pratiwi M. M. S. (2011). Tingkat Depresi pada Narapidana Wanita: Studi Deskriftif pada

Narapidana Lapas kelas II A Semarang. Asvattha: Journal Of Psychology.01,04,

Videbeck, S.L. (2008). Psychiatric mental health nursing. (4rd Ed.). Philadelphia: Lippincott Williams \& Wilkins. 